\title{
ANALISIS KUALITAS AIR DAERAH IRIGASI LUBUK ANTUK KECAMATAN HULU GURUNG KABUPATEN KAPUAS HULU
}

\author{
Zainal Wahyu 1, Syarifah Melly Maulina 1, Muji Listyo Widodo ${ }^{1 .}$ \\ ${ }^{1}$ Fakultas Teknik, Jurusan Teknik Sipil Universitas Panca Bhakti
}

\begin{abstract}
Abstrak
Desa Lubuk Antuk Kecamatan Hulu Gurung memiliki lahan daerah irigasi fungsional seluas 38,11 Ha. Saat ini petani maupun pemerintah daerah Kabupaten Kapuas Hulu belum mengetahui apakah air daerah irigasi Lubuk Antuk masih sesuai atau tidak untuk irigasi. Untuk menjawab kekhawatiran terhadap kualitas air irigasi yang digunakan maka perlu dilakukan penelitian kualitas air irigasi di Daerah Irigasi Lubuk Antuk. Pengambilan data untuk penelitian ini terdiri dari dua bagian, yaitu pengambilan sampel air di lapangan dan uji kualitas air di laboratorium. Dari hasil pemeriksaan kualitas air permukaan, dapat dilihat bahwa hampir semua parameter pencemaran air di lokasi masih berada dibawah baku mutu lingkungan kategori Air Kelas III berdasarkan Peraturan Pemerintah No. 82 Tahun 2001 tentang Pengelolaan Kualitas Air dan Pengendalian Pencemaran Air. Hanya satu parameter di titik lokasi yang melebihi baku mutu, yaitu BOD. Sehingga dapat dikatakan bahwa kualitas air irigasi di Daerah Irigasi Lubuk Antuk masih memenuhi baku mutu yang telah ditetapkan.
\end{abstract}

Kata kunci: irigasi; kualitas air; lubuk antuk

\begin{abstract}
[Title: Analysis of Water Quality of Lubuk Antuk Irrigation in Hulu Gurung Sub-District, Kapuas Hulu District] Lubuk Antuk Village, Hulu Gurung District has 38,11 Ha functional irrigation area. Currently farmers and the local government of Kapuas Hulu Regency do not yet know whether the water from the Lubuk Antuk irrigation area is still suitable or not for irrigation. To address concerns about the quality of irrigation water used, it is necessary to conduct research on the quality of irrigation water in the Lubuk Antuk Irrigation Area. Data collection for this study consisted of two parts, namely water sampling in the field and water quality testing in the laboratory. From the results of surface water quality inspection, it can be seen that almost all parameters of water pollution at the location are still below the environmental quality standards of the Class III Water category based on Government Regulation No. 82 of 2001 concerning Management of Water Quality and Control of Water Pollution. Only one parameter at the location point that exceeds the quality standard, namely BOD. So it can be said that the quality of irrigation water in the Lubuk Antuk Irrigation Area still meets the established quality standards.
\end{abstract}

Keywords: irrigation; lubuk antuk, water quality

\section{Pendahuluan}

Daerah irigasi Lubuk Antuk Kecamatan Hulu Gurung memiliki lahan daerah irigasi potensial seluas 270,54 Ha dan lahan daerah irigasi fungsional seluas 38,11 Ha. Hasil pertanian tanaman padi dari Lubuk Antuk diharapkan mampu memenuhi kebutuhan pangan masyarakat sekitar dan dapat dijadikan sebagai lumbung padi bagi Kabupaten Kapuas Hulu. Untuk menjadikan daerah Lubuk Antuk sebagai lumbung padi maka sangat

\footnotetext{
${ }^{*}$ Penulis Korespondensi.

E-mail: zwahyu2009@gmail.com muji.1.widodo@upb.ac.id
}

diperlukan ketahanan pangan yang stabil dan berkesinambungan. Guna menunjang ketahanan pangan maka lahan pertanian memerlukan debit air yang cukup dan kualitas air irigasi yang sesuai. Kualitas air irigasi yang tidak sesuai akan mengganggu pertumbuhan dan menurunkan produksi. Salah satu fungsi utama air bagi tanaman adalah untuk mengangkut unsur hara dari tanah ke dalam tubuh tanaman (Arifin, 2002).

Salah satu penyebab menurunnya kualitas air adalah terjadinya alih fungsi lahan. Terjadinya alih fungsi lahan ini sebagai akibat dari meningkatnya jumlah penduduk yang dibarengi dengan meningkatnya kebutuhan di luar sektor pertanian. Kebutuhankebutuhan di luar pertanian tersebut dapat berupa 
pemukiman, pariwisata, industri rumah tangga, peternakan, fasilitas umum, dan lainnya. Dengan adanya perubahan pemanfaatan ini akan menghasilkan limbah, baik padat, cair atau berupa sampah yang kerap kali dibuang ke sungai atau saluran irigasi. Kualitas air irigasi yang buruk dapat membahayakan pertumbuhan tanaman padi dan mengurangi produksi, yang berarti dapat menghambat program swasembada pangan.

Irigasi merupakan faktor yang sangat penting untuk mendukung produktivitas pertanian yang tinggi. Kebutuhan air untuk irigasi merupakan jumlah volume air yang diperlukan untuk memenuhi kebutuhan evaporasi, kehilangan air, dan kebutuhan air untuk tanaman dengan memperhatikan jumlah ketersediaan air yang diberikan oleh alam melalui air hujan dan lengas tanah. Kebutuhan air untuk tanaman ini dapat dipengaruhi oleh beberapa faktor seperti evaporasi, transpirasi dan jenis tanaman.

Irigasi merupakan upaya penyediaan dan pengaturan air untuk memenuhi kepentingan pertanian dengan memanfaatkan air yang berasal dari permukaan maupun air tanah dan mendistribusinya secara sistematis (Sosrodarsono dan Takeda, 2003). Menurut Peraturan Pemerintah (PP) No. 20 tahun 2006 tentang Irigasi, menyatakan bahwa irigasi merupakan usaha penyediaan, pengaturan dan pembuangan air irigasi untuk menunjang pertanian yang jenisnya meliputi irigasi permukaan, irigasi rawa, irigasi air bawah tanah, irigasi pompa, dan irigasi tambak. Selain untuk memenuhi kebutuhan air tanaman, irigasi atau pengairan ini dimaksudkan untuk mengolah tanah atau lahan guna memperbaiki tata udara tanah, menciptakan kondisi lumpur sebagai tempat tumbuh yang baik bagi tanaman, membantu dalam pembentukan lapisan kedap air, serta sebagai salah satu upaya memberantas gulma (Supriatno, 2003 dalam Akmal dkk, 2014).

Air yang digunakan sebagai sumber irigasi harus memenuhi syarat atau baku mutu kualitas air tertentu agar tidak membahayakan tanaman dan tidak mempengaruhi hasil tanaman dalam jangka waktu tertentu. Kualitas air irigasi ini dipengaruhi oleh kandungan sedimen dan unsur-unsur kimia yang terkandung di air (Schwab dkk, 1981 dalam Kurnia, 2004). Selain itu, karakter fisik seperti suhu juga memiliki pengaruh yang cukup besar bagi pertumbuhan tanaman. Sedimen dalam tanah akan berpengaruh terhadap permeabilitas tanah dan menurunkan kesuburan tanah. Apabila sedimen ini terkandung dan mengendap dalam saluran irigasi, maka akan berpengaruh pada kapasitas pengaliran air dan air akan menjadi keruh. Selain kandungan sedimen, unsur kimia juga dapat berpengaruh terhadap kualitas air irigasi. Sifat-sifat kimia dalam air sebagai sumber irigasi pertanian yang penting diketahui meliputi konsentrasi garam terlarut, proporsi garam terhadap kation lain, konsentrasi unsur beracun, konsentrasi bikarbonat, dan kandungan logam berat. Saat ini petani maupun pemerintah daerah Kabupaten Kapuas Hulu belum mengetahui apakah air daerah irigasi Lubuk Antuk masih sesuai atau tidak untuk irigasi. Untuk menjawab kekhawatiran terhadap kualitas air irigasi yang digunakan maka berdasarkan uraian di atas perlu dilakukan penelitian kualitas air irigasi di Daerah Irigasi Lubuk Antuk.

\section{Bahan dan Metode}

Metode yang digunakan dalam penelitian ini adalah metode deskriptif dengan pendekatan kuantitatif. Penelitian ini merupakan penelitian lapangan dan laboratorium. Alat dan bahan yang digunakan dalam penelitian ini yaitu sebagai berikut:

a. Air di daerah irigasi Lubuk Antuk.

b. Botol/jerigen untuk wadah pengambilan sampel air di lokasi penelitian.

c. Global Positioning System (GPS) untuk mengetahui posisi pengambilan sampel.

d. Alat bantu seperti ember, meteran, tali, gunting dan alat-alat tulis.

e. Untuk di laboratorium bahan dan alat meliputi zat kimia dan peralatan analisa air.

f. Software Microsoft Office untuk mengolah dan menganalisis data

Pengambilan data untuk penelitian ini terdiri dari dua bagian, yaitu pengambilan sampel air di lapangan dan uji kualitas air di laboratorium. Pengambilan sampel air di lapangan sekaligus pengamatan terhadap sumber pencemar, jenis pencemar dan mekanisme pembuangan limbah. Untuk mengetahui kelayakan kualitas air irigasi padi sawah, sampel air di lokasi penelitian diambil dengan menggunakan botol sampel pada setiap titik sampel. Lokasi sampel air yang akan diuji di laboratorium diambil di Embung.

Uji laboratorium dilakukan untuk mengetahui seberapa besar kandungan parameter unsur mayor dalam sampel air. Parameter kualitas air yang ditentukan di laboratorium adalah Konduktivitas atau Daya Hantar Listrik (DHL), Padatan terlarut (TDS), Kemasaman $(\mathrm{pH})$, Kalsium (Ca), Magnesium $(\mathrm{Mg})$, Natrium $(\mathrm{Na})$, Karbonat (CO3), Bikarbonat (HCO3), Sulfat (SO4), Klorida (Cl), Kalium (K), Nitrat (NO3) dan Boron (B). Untuk mengetahui kelayakan air untuk irigasi maka hasil nilai parameter yang sudah dianalisa dicocokan dengan standar yang sudah ada.

\section{Hasil dan Pembahasan}

Lokasi Kegiatan Jaringan Irigasi terletak di Desa Lubuk Antuk Kecamatan Hulu Gurung Kabupaten Kapuas Hulu Provinsi Kalimantan Barat dengan letak geografis $0,35^{\circ} \mathrm{LU}-0,46^{\circ} \mathrm{LU}$ (garis lintang) dan $112,22^{0} \mathrm{BT}-112,38^{0} \mathrm{BT}$ (garis bujur).

Sebelum melakukan pengukuran kualitas dilakukan pengumpulan data terhadap stakeholder terkait yaitu Dinas Pekerjaan Umum Kabupaten Kapuas 
Hulu. Pengukuran kualitas air dilokasi kegiatan jaringan irigasi dilakukan pada 1 (satu) lokasi yaitu Embung (koordinat: $112^{\circ} 16$ ' 13,84" BT - 00 20' 42,73" LU). Hasil analisa pengukuran kualitas air yang digunakan pada operasional jaringan irigasi berdasarkan PP RI No. 82 Tahun 2001 Tentang Pengelolaan Kualitas Air dan Pengendalian Pencematn Air, Kategori Air Kelas III dapat dilihat pada Tabel 1.

Tabel 1. Hasil Analisa Pengukuran Air

\begin{tabular}{|c|c|c|c|c|}
\hline \multirow[t]{2}{*}{ No } & \multirow[t]{2}{*}{ Parameter } & \multirow[t]{2}{*}{ Satuan } & \multirow[t]{2}{*}{$\begin{array}{c}\text { Kelas Mutu Air } \\
\text { (Kelas III) }\end{array}$} & \multirow{2}{*}{$\begin{array}{c}\begin{array}{c}\text { Hasil } \\
\text { Pemeriksaan }\end{array} \\
\text { Al }\end{array}$} \\
\hline & & & & \\
\hline 1. & Residu Tersuspensi (TSS) & $\mathrm{mg} / \mathrm{L}$ & 400 & 37 \\
\hline 2. & Residu Terlarut (TDS) & $\mathrm{mg} / \mathrm{L}$ & 1000 & 21 \\
\hline 3. & Temperature & ${ }^{\circ} \mathrm{C}$ & Deviasi 3 & 24,9 \\
\hline 4. & Turbidity & Skala NTU & 25 & 3 \\
\hline 5. & Warna & Pt. Co & 50 & 16 \\
\hline 6. & Arsen (As) & $\mathrm{mg} / \mathrm{L}$ & 1 & 0,00 \\
\hline 7. & Amoniak $\left(\mathrm{NH}_{4}\right)$ & $\mathrm{mg} / \mathrm{L}$ & $(-)$ & 0,02 \\
\hline 8. & $\operatorname{Besi}(\mathrm{Fe})$ & $\mathrm{mg} / \mathrm{L}$ & $(-)$ & 0,19 \\
\hline 9. & $\mathrm{COD}$ & $\mathrm{mg} / \mathrm{L}$ & 50 & 24 \\
\hline 10. & BOD & $\mathrm{mg} / \mathrm{L}$ & 6 & 11 \\
\hline 11. & DO & $\mathrm{mg} / \mathrm{L}$ & 3 & 5,2 \\
\hline 12. & Flourida (F) & $\mathrm{mg} / \mathrm{L}$ & 1,5 & 0,00 \\
\hline 13. & Klorida (Cl) & $\mathrm{mg} / \mathrm{L}$ & $(-)$ & 5 \\
\hline 14. & Klorin bebas (sebagai $\mathrm{Cl}_{2}$ ) & $\mathrm{mg} / \mathrm{L}$ & 0,03 & 0,00 \\
\hline 15. & Kromium valensi $6\left(\mathrm{Cr}^{6}\right)$ & $\mathrm{mg} / \mathrm{L}$ & 0,05 & 0,00 \\
\hline 16. & Kalsium $(\mathrm{Ca})$ & $\mathrm{mg} / \mathrm{L}$ & 200 & 2,6 \\
\hline 17. & Kesadahan $(\mathrm{CaC} 03)$ & $\mathrm{mg} / \mathrm{L}$ & 500 & 10 \\
\hline 18. & Merkuri (Hg) & $\mathrm{mg} / \mathrm{L}$ & 0,002 & $<0,001$ \\
\hline 19. & Mangan (Mn) & $\mathrm{mg} / \mathrm{L}$ & $(-)$ & 0,01 \\
\hline 20. & Nitrat $\left(\mathrm{NO}_{3}\right)$ & $\mathrm{mg} / \mathrm{L}$ & 20 & 0,015 \\
\hline 21. & Nitrit $\left(\mathrm{NO}_{2}\right)$ & $\mathrm{mg} / \mathrm{L}$ & 0,06 & 0,002 \\
\hline 22. & $\mathrm{pH}$ & & $6,0-9,0$ & 7,73 \\
\hline 23. & Seng $(Z n)$ & $\mathrm{mg} / \mathrm{L}$ & 0,05 & 0,01 \\
\hline 24. & Sianida $(\mathrm{CN})$ & $\mathrm{mg} / \mathrm{L}$ & 0,02 & 0,00 \\
\hline 25. & Sulfat $\left(\mathrm{SO}_{4}\right)$ & $\mathrm{mg} / \mathrm{L}$ & $(-)$ & $<0,4629$ \\
\hline 26. & Sulfida $\left(\mathrm{H}_{2} \mathrm{~S}\right)$ & $\mathrm{mg} / \mathrm{L}$ & 0,002 & 0,00 \\
\hline 27. & Timbal $(\mathrm{Pb})$ & $\mathrm{mg} / \mathrm{L}$ & 0,03 & 0,00 \\
\hline 28. & Tembaga $(\mathrm{Cu})$ & $\mathrm{mg} / \mathrm{L}$ & 0,02 & 0,009 \\
\hline & Total Fosphate $\left(\mathrm{PO}_{4}\right)$ & $\mathrm{mg} / \mathrm{L}$ & 1 & 0,01 \\
\hline & Fenol & $\mu g / L$ & 1 & 0,00 \\
\hline & Minyak \& Lemak & $\mu \mathrm{g} / \mathrm{L}$ & 1000 & 0,00 \\
\hline 32. & Deterjen (MBAS) & $\mu g / \mathrm{L}$ & 200 & 0,00 \\
\hline
\end{tabular}

Sumber : Unit Laboratorium Kesehatan Dinas Kesehatan Provinsi Kalimantan Barat, 2019

Dari hasil pemeriksaan kualitas air permukaan di atas, dapat dilihat bahwa hampir semua parameter pencemaran air di lokasi masih berada dibawah baku mutu lingkungan kategori Air Kelas III berdasarkan Peraturan Pemerintah No. 82 Tahun 2001. Hanya satu parameter yang melebihi baku mutu yaitu BOD.

\section{Parameter Fisika}

Parameter fisika yang dianalisis meliputi residu tersuspensi (TSS), residu terlarut (TDS), warna, dan turbidity/ kekeruhan yang dijabarkan dalam uraian sebagai berikut.

\section{a. $\quad$ Residu Tersuspensi/ Total Suspended Solid (TSS)}

Zat padat tersuspensi/ Total Suspended Solid (TSS) merupakan tempat berlangsungnya reaksi-reaksi kimia yang heterogen, dan berfungsi sebagai bahan pembentuk endapan yang paling awal dan dapat menghalangi kemampuan produksi zat organik di suatu perairan. Penetrasi cahaya matahari ke permukaan dan bagian yang lebih dalam tidak berlangsung efektif akibat terhalang oleh zat padat tersuspensi, sehingga fotosintesis tidak berlangsung sempurna. Sebaran zat padat tersuspensi di laut selain dipengaruhi oleh masukan yang berasal dari darat melalui aliran sungai, juga dapat berasal dari udara dan perpindahan karena resuspensi endapan akibat pengikisan.

Kadar TSS di lokasi pengamatan adalah $37 \mathrm{mg} / \mathrm{L}$, dengan baku mutu lingkungan untuk kategori kelas III yaitu sebesar $400 \mathrm{mg} / \mathrm{L}$. Hal ini menunjukkan adanya bahan padatan yang berasal dari daratan masuk ke perairan sehingga menganggu keseimbangan ekosistem perairan tersebut, namun tidak terlalu banyak jumlahnya. Tingginya kadar TSS juga dapat bersumber dari semua zat padat (pasir, lumpur, dan tanah liat) atau partikel-partikel yang tersuspensi dalam air dan dapat berupa komponen hidup (biotik) seperti fitoplankton, zooplankton, bakteri, fungi, ataupun komponen mati (abiotik) seperti detritus dan partikel-partikel anorganik. Total Suspended Solid (TSS) sangat berpengaruh terhadap tingkat kecerahan dan kekeruhan air (turbiditas).

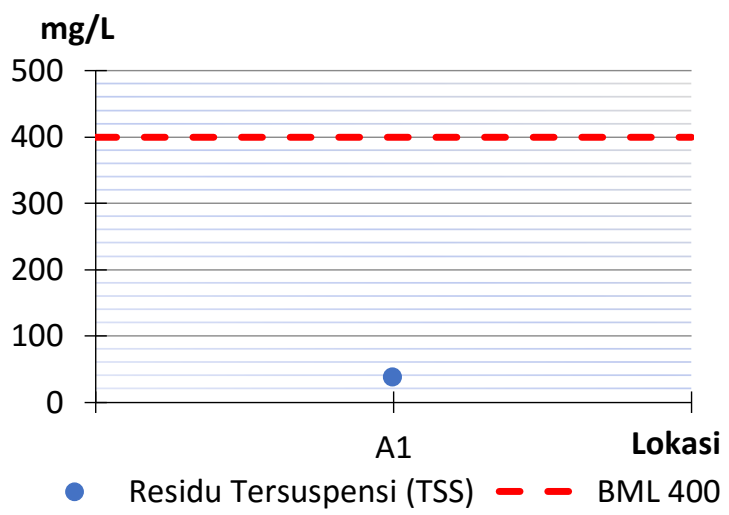

Gambar 1. Total Suspended Solid (TSS)

\section{b. Residu Terlarut/Total Dissolved Solid (TDS)}

Secara umum, konsentrasi benda-benda padat terlarut merupakan jumlah antara anion dan kation didalam air. Benda-benda padat didalam air tersebut dapat berasal dari berbagai sumber misalnya bahan organik seperti daun, lumpur, plankton, limbah industri dan kotoran. Selain tiu, TDS juga dapat berasal dari bahan anorganik seperti batu dan udara yang mungkin mengandung kalsium bikarbonat, nitrogen, besi, sulfur dan mineral lainnya. Sebagian besar dari bahan-bahan ini membentuk garam ayng merupakan senyawa yang mengandung logam dan non logam. Kadar TDS di 
lokasi pengamatan pada titik lokasi adalah $21 \mathrm{mg} / \mathrm{L}$. Konsentrasi TDS tersebut masih berada dibawah baku mutu yang telah ditetapkan yaitu sebesar $1.000 \mathrm{mg} / \mathrm{L}$ untuk kategori baku mutu air kelas III. Konsentrasi TDS di lokasi pemantauan dapat dilihat pada gambar berikut.

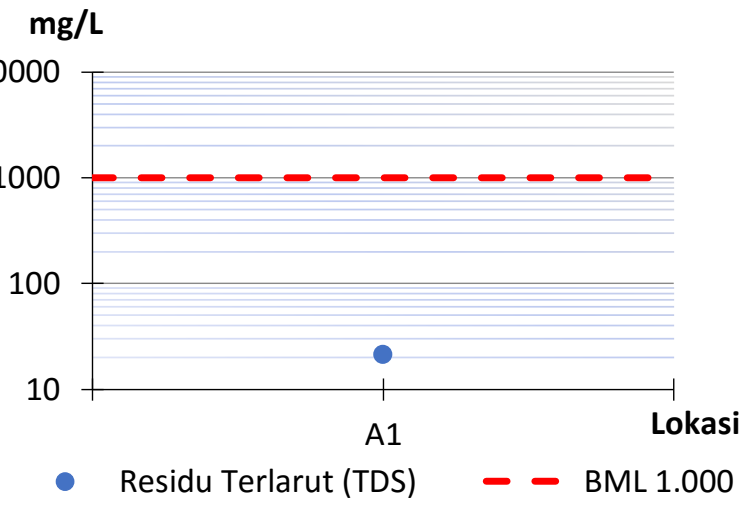

Gambar 2. Total Dissolved Solid (TDS)

\section{c. Warna}

Dari hasil pengujian kualitas air terlihat kadar warna pada lokasi pemantauan berada di bawah baku mutu yaitu 16 Pt.Co, sedangkan baku mutu yang telah ditetapkan adalah 50 Pt.Co. Tingginya suatu kadar warna dapat disebabkan oleh adanya kandungan bahanbahan organik dan anorganik seperti keberadaan plankton, humus, dan ion-ion logam (misalnya besi, mangan dan lain-lain), bahan buangan dari limbah rumah tangga, pasar maupun produksi rumah tangga lainnya. Adanya oksida besi menyebabkan air berwarna kemerahan, sedangkan oksida mangan menyebakan air berwarna kecokelatan atau kehitaman. Bahan organik misalnya tangin, lignin, dan asam humus yang berasal dari dekomposisi tumbuhan yang telah mati, sehingga menimbulkan warna kecokelatan.

\section{Pt. Co}

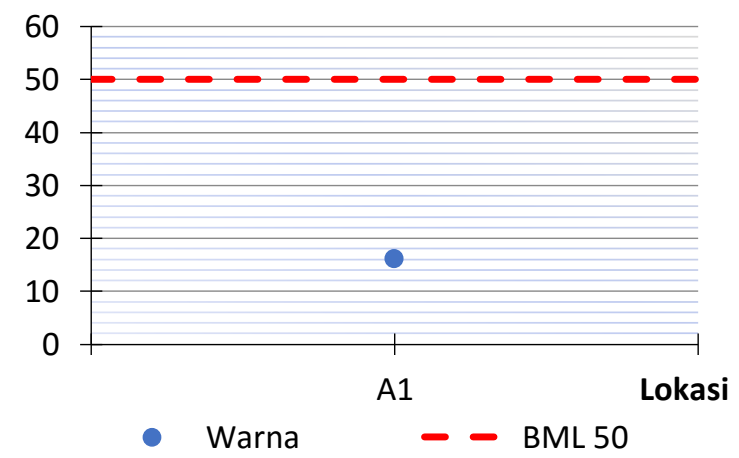

Gambar 3. Warna

Warna dapat diamati secara visual (langsung) ataupun diukur berdasarkan skala Platinum Kobalt (Pt.Co), dengan membandingkan warna air sampel dan standar warna yang ditetapkan pemerintah. Standar air yang memiliki kekeruhan rendah biasanya memiliki warna tampak dan warna sesungguhnya yang sama dengan standar. Ditetapkannya standar warna sebagai salah satu persyaratan kualitas, diharapkan bahwa semua air minum yang akan diberikan kepada masyarakat akan dapat langsung diterima oleh masyarakat.

\section{d. Kekeruhan (Turbidity)}

Kekeruhan (turbidity) merupakan jumlah dari butir-butir zat yang tergenang dalan air. Kekeruhan menggambarkan sifat optik air yang ditentukan berdasarkan banyaknya cahaya yang diserap dan dipancarkan oleh bahan-bahan yang terdapat di dalam air. Kekeruhan disebabkan adanya bahan organik dan anorganik yang tersuspensi dan terlarut (misalnya lumpur dan pasir halus), maupun bahan anorganik dan organik yang berupa plankton dan mikroorganisne lain (APHA, 1976; Davis dan Cornwell, 1991 dalam Effendi 2003). Zat anorganik yang menyebabkan kekeruhan dapat berasal dari pelapukan batuan dan logam, sedangkan zat organik berasal dari lapukan hewan dan tumbuhan.

Tingkat kekeruhan (turbidity) pada lokasi pemantauan adalah 3 skala NTU, dengan hasil tersebut tersebut tingkat kekeruhan tidak melebihi baku mutu lingkungan yang ditentukan. Tinggi rendahnya nilai kekeruhan dapat dipengaruhi oleh adanya bahan tersuspensi pada perairan berupa partikel tanah liat, lumpur, koloid tanah dan organisme perairan (mikroorganisme). Semakin tinggi nilai padatan tersuspensi, semakin tinggi nilai kekeruhan. Akan tetapi, tingginya padatan terlarut tidak selalu diikuti dengan tingginya kekeruhan. Tingginya nilai kekeruhan dapat mengakibatkan terjadinya gangguan respirasi, dapat menurunkan kadar oksigen dalam air, terganggunya daya lihat (visual) organisme akuatik, terjadinya gangguan terhadap habitat, menghambat penetrasi cahaya ke dalam air, mengurangi efektifitas desinfeksi pada proses penjernihan air.

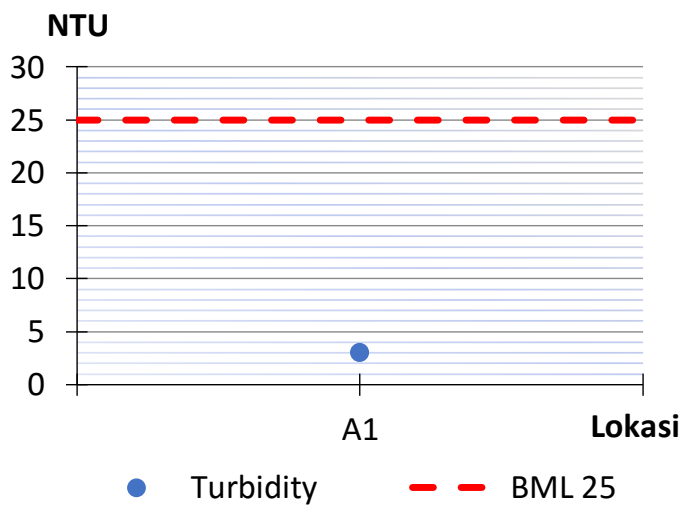

Gambar 4. Kekeruhan (Turbidity) Parameter Kimia

Berdasarkan hasil analisis laboratorium terhadap parameter-parameter kimia, menunjukkan bahwa kondisi wilayah studi secara umum dinyatakan masih 
berada di bawah kadar maksimum yang diperbolehkan. Kondisi ini disebabkan oleh kondisi perairan sungai di wilayah studi menunjukkan bahwa daya dukung lingkungan yang ada masih dapat menekan beban pencemaran, namun jika tidak ditanggulangi dengan benar akan mengakibatkan pencemaran yang tinggi bagi lingkungan itu sendiri. Parameter-parameter kimia yang dianalisis antara lain adalah:

\section{a. Arsen (As)}

Di perairan alami Arsen membentuk arsenat $\left(\mathrm{AsO}_{4}{ }^{3-}\right)$ atau Arsenit $\left(\mathrm{AsO}_{3}{ }^{3-}\right)$. Senyawa anorganik Arsen dapat dirubah secara biologis menjadi senyawa Organo Arsen yang bersifat toksik. Sumber Arsen diperairan adalah logam Arsenide dan Sulfida. Kadar Arsen pada perairan tawar sekitar $0,01 \mathrm{mg} / \mathrm{L}$. Untuk menjaga ekosistem akuatik, kadar Arsen sebaiknya tidak lebih dari 0,05 mg/L. Untuk keperluan air minum, kadar Arsen sebaiknya tidak melebihi $1 \mathrm{mg} / \mathrm{L}$ sesuai dengan baku mutu kelas III. Hasil laboratorium untuk kandungan arsenic pada lokasi studi tidak terdeteksi yang menandakan bahwa kandungan arsenic sangat kecil bahkan nihil, seperti terlihat pada gambar berikut:

\section{$\mathrm{mg} / \mathrm{L}$}

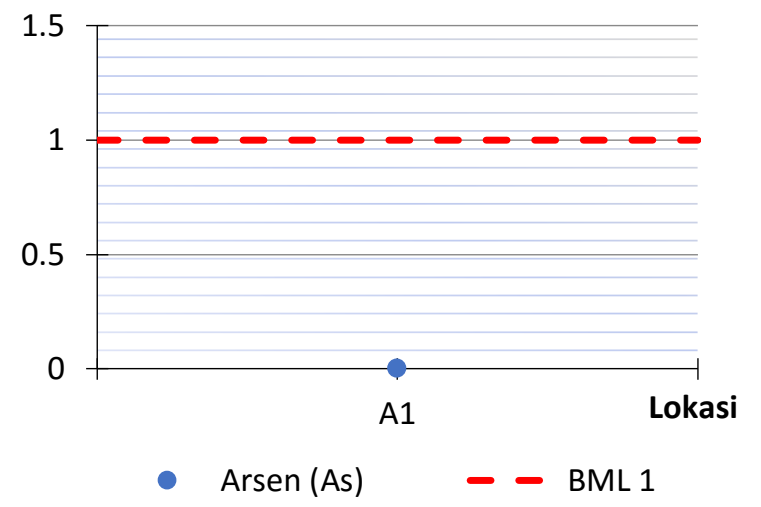

Gambar 5. Arsen (As)

\section{b. Amoniak $\left(\mathrm{NH}_{4}\right)$}

Di perairan alami, pada suhu dan tekanan normal amoniak dalam bentuk gas dan membentuk kesetimbangan dengan ion amonium. Selain terdapat dalam bentuk gas, amoniak juga membentuk kompleks dengan beberapa ion logam. Amoniak juga dapat terserap ke dalam bahan-bahan tersuspensi dan koloid sehingga mengendap di dasar peraiaran. Amoniak di perairan dapat menghilang melalui proses volatilisasi karena tekanan parsial amoniak dalam larutan meningkat dengan semakin meningkatnya $\mathrm{pH}$. Amoniak dan garam-garamnya bersifat mudah larut dalam air. Dari hasil uji laboratorium, kadar amoniak $\left(\mathrm{NH}_{4}\right)$ di lokasi adalah 0,02 mg/L. Kadar amoniak pada air sungai tersebut dapat berasal dari oksidasi zat organik secara mikrobiologis yang berasal dari air alam atau buangan (domestik dan non domestik). Konsentrasi amoniak yang tinggi pada permukaan air akan menyebabkan kematian mikroorganisme seperti ikan yang terdapat pada perairan tersebut.

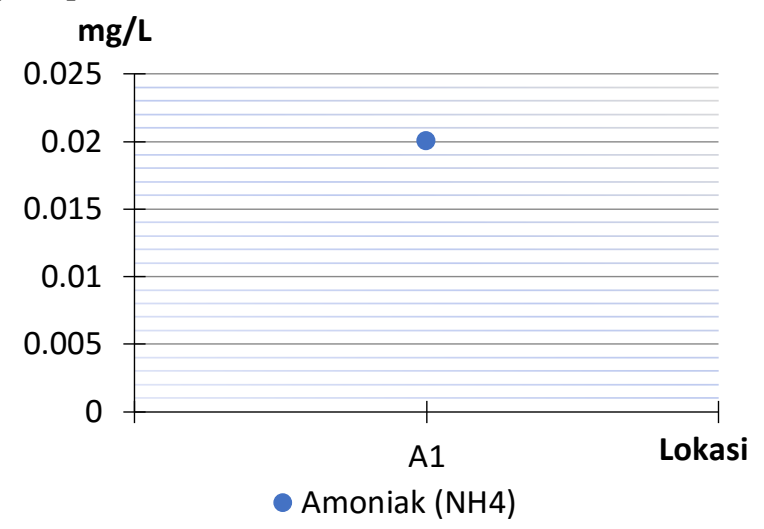

Gambar 6. Amoniak $\left(\mathrm{NH}_{4}\right)$

\section{c. Besi (Fe)}

Besi (Fe) merupakan salah satu elemen kimia yang dapat ditemui pada hampir setiap tempat di bumi, pada semua lapisan geologi dan semua badan air. Zat besi dapat ditemukan secara alami pada air tanah dan beberapa air permukaan (seperti anak sungai, sungai dan sumur yang dangkal). Ada beberapa wilayah di dunia yang memiliki kadar zat besi tinggi secara alami pada air tanahnya. Besi ditemukan dalam bentuk kation Fero $\left(\mathrm{Fe}^{2+}\right)$ dan kation Feri $\left(\mathrm{Fe}^{3+}\right)$.

Pada perairan alami dengan $\mathrm{pH}$ sekitar 7 dan kadar Oksigen terlarut yang cukup, ion Fero yang bersifat mudah larut dioksidasikan menjadi ion Feri. Besi hanya ditemukan pada perairan yang bersifat anaerob, akibat proses dekomposisi bahan organik yang berlebihan. Jadi di perairan, kadar besi yang tinggi terdapat pada air yang berasal air tanah dalam yang bersuasana anaerob atau dari lapisan dasar perairan yang sudah tidak mengandung oksigen.

\section{$\mathrm{mg} / \mathrm{L}$}

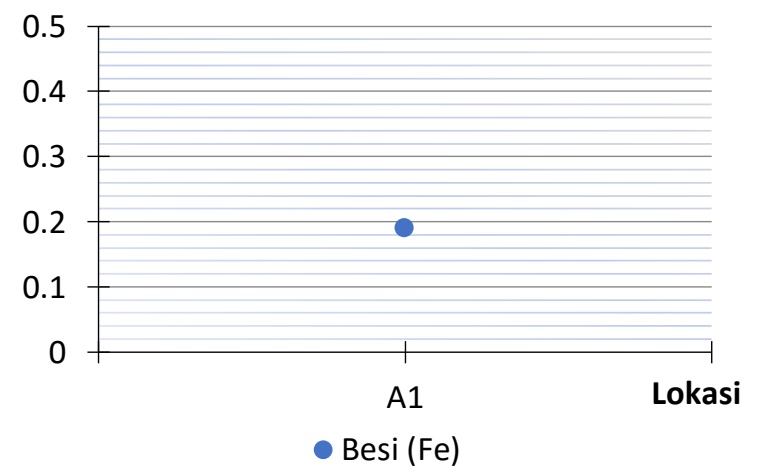

Gambar 7. Besi (Fe)

Kadar besi pada perairan yang mendapat cukup aerasi (aerob) hampir tidak lebih dari 0,3 mg/L. Kadar besi lebih dari 1,0 mg/L dianggap membahayakan bagi kehidupan organisme akuatik. Air yang diperuntukkan 
bagi air minum sebaiknya mengandung kadar besi kurang dari $0,3 \mathrm{mg} / \mathrm{L}$ dan perairan yang diperuntukkan untuk pertanian sebaiknya memiliki kadar besi tidak lebih dari $20 \mathrm{mg} / \mathrm{L}$. Adapun kadar besi pada pengukuran air sungai di lokasi adalah $0,19 \mathrm{mg} / \mathrm{l}$. Kadar besi yang tinggi ini dapat menyebabkan warna air berubah kemerahan.

\section{d. Chemical Oxygen Demand (COD)}

Chemical Oxygen Demand (COD) merupakan jumlah oksigen yang diperlukan untuk menguraikan seluruh bahan organik yang terkandung dalam air melalui reaksi oksidasi. Proses oksidasi tersebut memerlukan oksigen sesuai dengan kandungan bahan kimia dalam air. Angka COD merupakan ukuran zat organik yang secara alamiah dapat dioksidasi dan mengakibatkan berkurangnya oksigen terlarut dalam air. Nilai COD yang terukur di lokasi pemantauan adalah 24 $\mathrm{mg} / \mathrm{l}$. Jika dibandingkan dengan standar baku mutu lingkungan berdasarkan Peraturan Pemerintah Republik Indonesia No 82 tahun 2001 kategori air kelas III, dapat dilihat bahwa hasil pengukuran COD di lokasi tersebut berada di bawah baku mutu yaitu sebesar $50 \mathrm{mg} / \mathrm{L}$.

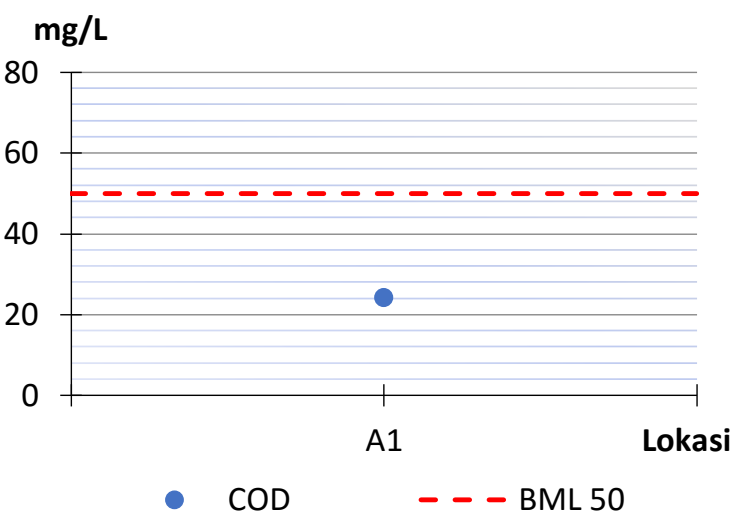

Gambar 8. Chemical Oxygen Demand (COD)

\section{e. Biochemical Oxygen Demand (BOD)}

Biochemical Oxygen Demand (BOD) adalah jumlah oksigen terlarut yang diperlukan oleh mikroorganisme untuk menguraikan atau mendekomposisi bahan organik dalam kondisi aerobik. Nilai BOD bisa saja sama dengan nilai COD, tetapi tidak bisa lebih besar dari nilai COD, karena COD merupakan total senyawa kimia yang terkandung didalam air, sementara selisih dari nilai COD dan BOD menggambarkan bahan kimia yang sulit terurai. Tingginya BOD menggambarkan bahwa di perairan tersebut mengandung bahan organik tinggi karena lokasi pemantauan berjenis tanah gambut. Sebaliknya nilai BOD yang rendah belum tentu menunjukkan kandungan bahan organiknya rendah. Karena tidak semua bahan organik dapat terdekomposisi secara biologis (biodegradable). Hasil pengukuran konsentrasi BOD di lokasi adalah $11 \mathrm{mg} / \mathrm{L}$, dengan baku mutu adalah sebesar $6 \mathrm{mg} / \mathrm{l}$. Hal ini menunjukkan bahwa konsentrasi BOD tergolong tinggi dan melebihi baku mutu lingkungan yang telah ditetapkan. Dilihat dari rasio nilai BOD dan COD perairan di wilayah studi, diperkirakan organik yang ada adalah organik yang mudah terurai secara biologi oleh mikro organisme pengurai sehingga menyebabkan mikroba menjadi aktif dan menguraikan bahan organik tersebut secara biologis menjadi senyawa asam-asam organik.

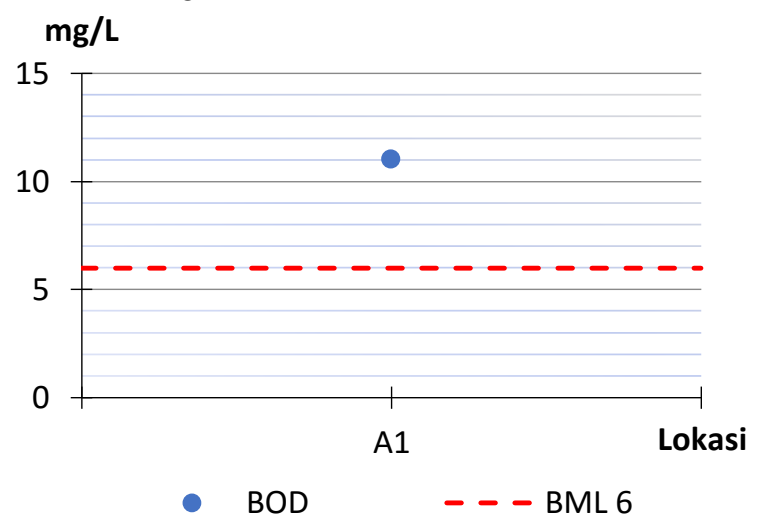

Gambar 9. Biochemical Oxygen Demand (BOD)

\section{f. Clorida Bebas}

Clorida bebas adalah ion Clorida dan ion Hipoklarit yang tidak berikatan dengan senyawa lain. Menurut PP No. 82 Tahun 2001 kategori air kelas III, kadar maksimum Chlorida bebas yang diperkenankan adalah $0,03 \mathrm{mg} / \mathrm{L}$. Kandungan Clorida bebas pada lokasi pemantauan adalah $0,00 \mathrm{mg} / \mathrm{L}$. Dengan demikian kandungan Clorida bebas pada lokasi studi lainnya berada di bawah baku mutu yang diperbolehkan.

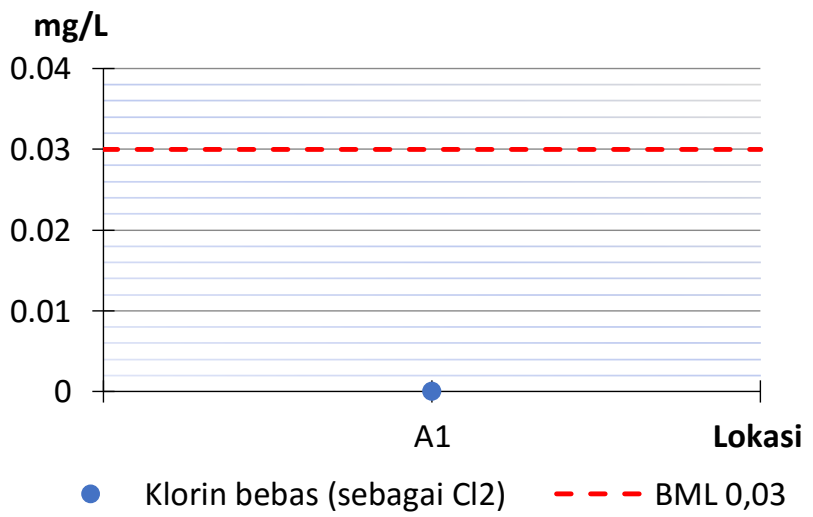

Gambar 10. Klorin Bebas (sebagai $\mathrm{Cl}_{2}$ )

\section{g. Dissolve Oxygen (DO)}

Oksigen terlarut (DO) sangat esensial bagi pernafasan dan merupakan salah satu komponen utama bagi metabolisme biota air. Oksigen di perairan berasal dari atmosfir dan proses fotosintesa (Chrost dan Siuda, 2006). Adanya angin dan arus air yang menyebabkan proses aerasi dapat berlangsung dengan baik, sehingga 
kandungan oksigen terlarutnya cukup besar. Kandungan DO di lokasi adalah 5,2 mg/L. Dengan demikian nilai tersebut masih baik, karena kandungan oksigen tidak boleh berada dibawah baku mutu yang ditentukan yaitu $3 \mathrm{mg} / \mathrm{L}$. Kandungan DO untuk masing-masing titik dapat dilihat pada gambar berikut.

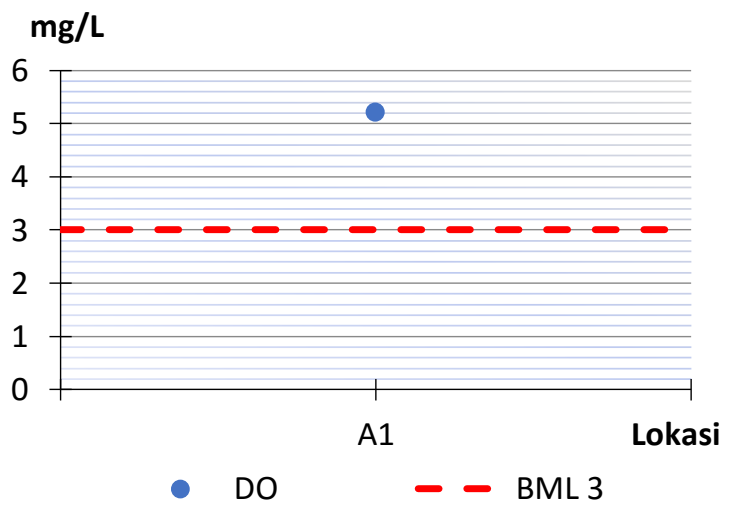

Gambar 11. Dissolved Oxygen (DO)

\section{h. Fluorida (F)}

Flour merupakan salah satu unsur yang melimpah pada kerak bumi. Unsur ini ditemukan dalam bentuk ion flourida. Perairan alami biasanya memiliki kadar fluorida kurang dari 0,2 mg/L. Dari hasil pemantauan kualitas air permukaan, diperoleh kadar fluorida di lokasi adalah 0,00 mg/l, sedangkan baku mutu lingkungan adalah sebesar $1,5 \mathrm{mg} / \mathrm{l}$. Hal ini menunjukkan kadar fluorida yang masih tergolong baik, karena berada jauh dibawah baku mutu. Sejumlah kecil flourida terbukti menguntungkan bagi pencegahan kerusakan gigi, akan tetapi konsentrasi yang berlebih pada kisaran $1,7 \mathrm{mg} / \mathrm{L}$ dapat mengakibatkan pewarnaan gigi.

\section{$\mathrm{mg} / \mathrm{L}$}

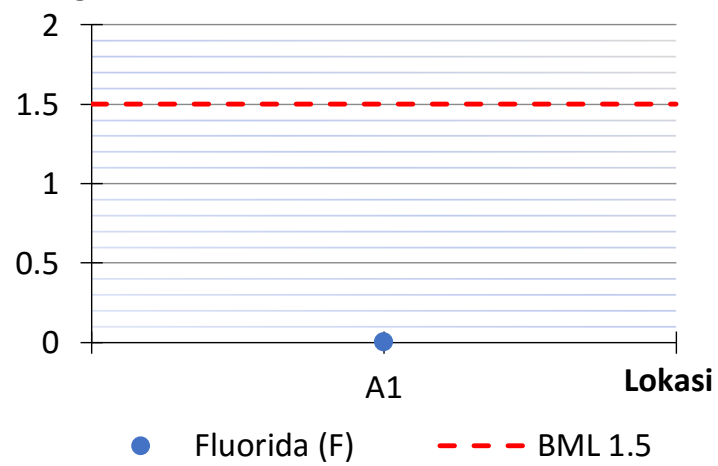

Gambar 12. Flourida (F)

\section{i. Chlorida $(\mathbf{C l})$}

Ion Clorida adalah anion yang di perairan laut. Sekitar $75 \%$ clorin yang terdapat di bumi berada dalam bentuk larutan. Keberadaan clorida pada perairan alami berkisar antara $20-30 \mathrm{mg} / \mathrm{L}$. Clorida tidak bersifat toksik bagi mahluk hidup, bahkan berperan dalam pengaturan tekanan sel. Perairan yang diperuntukan bagi keperluan, termasuk air minum, pertanian dan industri, sebaiknya memiliki kadar clorida lebih kecil dari $600 \mathrm{mg} / \mathrm{L}$. Kandungan chlorida $(\mathrm{Cl})$ di lokasi pemantauan adalah 5 $\mathrm{mg} / \mathrm{l}$.

$\mathrm{mg} / \mathrm{L}$

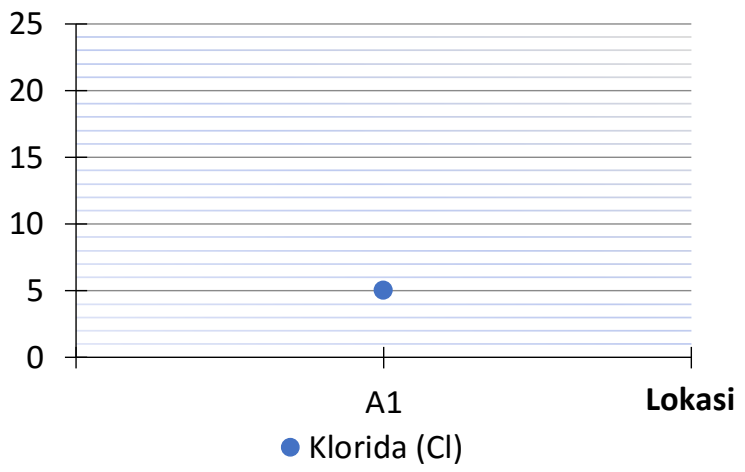

Gambar 13. Klorida $(\mathrm{Cl})$

\section{j. Kandungan Air Raksa/Merkuri (Hg)}

Merkuri adalah unsur renik pada kerak bumi, yakni hanya sekitar $0,08 \mathrm{mg} / \mathrm{kg}$. Pada perairan alami, merkuri juga ditemukan dalam jumlah yang sangat kecil. Merkuri merupakan satu-satunya logam yang berbentuk cairan pada suhu normal. Merkuri terserap dalam bahanbahan partikulat, dan mengalami presipitasi. Pada dasar perairan anaerobic, merkuri berikatan dengan sulphur. Kadar merkuri pada air minum sebaiknya tidak melebihi $0,002 \mathrm{mg} / \mathrm{L}$. Kadar merkuri antara 0,001 mg/1 - 0,01 $\mathrm{mg} / \mathrm{L}$ dapat menghambat pertumbuhan microalgae. Hasil analisa menunjukkan kadar merkuri di bawah baku mutu kelas III. Kandungan Air Raksa/merkuri (Hg) di lokasi pemantauan adalah $<0,001 \mathrm{mg} / \mathrm{L}$, masih berada di bawah kadar maksimum $\mathrm{Hg}$ yang diperbolehkan $(0,002 \mathrm{mg} / \mathrm{L})$.

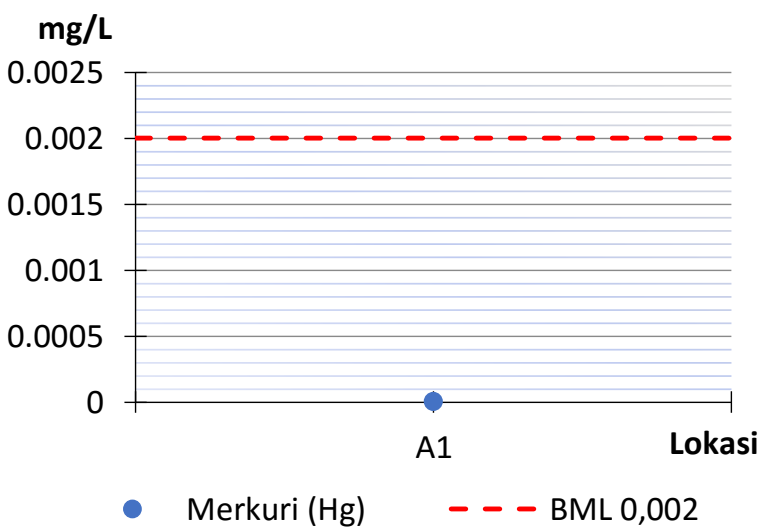

Gambar 14. Merkuri (Hg)

\section{k. Mangan (Mn)}

Kadar mangan (Mn) yang terkandung dalam perairan disekitar lokasi adalah 0,01 mg/l. Umumnya, mangan terbentuk bersamaan dengan zat besi. Namun, 
aktivitas manusia juga dapat menjadi penyebab kontaminasi mangan di beberapa perairan. Konsentrasi mangan yang tinggi dapat mengubah warna air menjadi kecoklatan atau kehitaman. Hal ini juga menyebabkan rasa air berubah. Konsentrasi mangan yang meningkat pada sungai kemungkinan tercemar oleh aktivitas pertambangan atau oleh aktivitas alam itu sendiri.

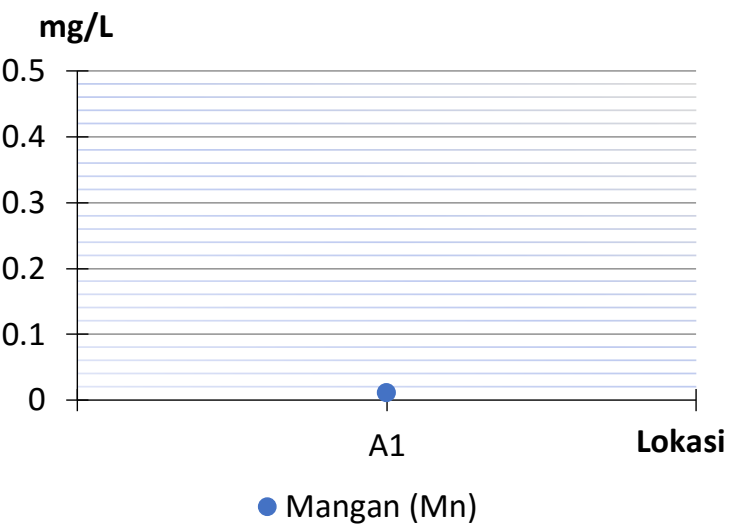

Gambar 15. Mangan (Mn)

\section{Kandungan Nitrat $\left(\mathrm{NO}_{3}\right)$}

Nitrogen merupakan komponen utama protein yang penting bagi pertumbuhan organisme. Di perairan nitrogen terdapat dalam bentuk gas $\left(\mathrm{N}_{2}\right)$, nitrit $\left(\mathrm{NO}_{2}\right)$, nitrat $\left(\mathrm{NO}_{3}\right)$ dan amoniak $\left(\mathrm{NH}_{3}\right)$. Senyawa-senyawa ini di dalam perairan alami sebagai garam-garam terlarut, tersuspensi dan endapan. Kandungan nitrat $\left(\mathrm{NO}_{3}\right)$ air permukaan di lokasi pemantauan adalah $0,015 \mathrm{mg} / \mathrm{L}$. Dengan demikian kandungan nitrat diseluruh lokasi studi masih berada di bawah kadar maksimum yang diperbolehkan yaitu $20 \mathrm{mg} / \mathrm{L}$.

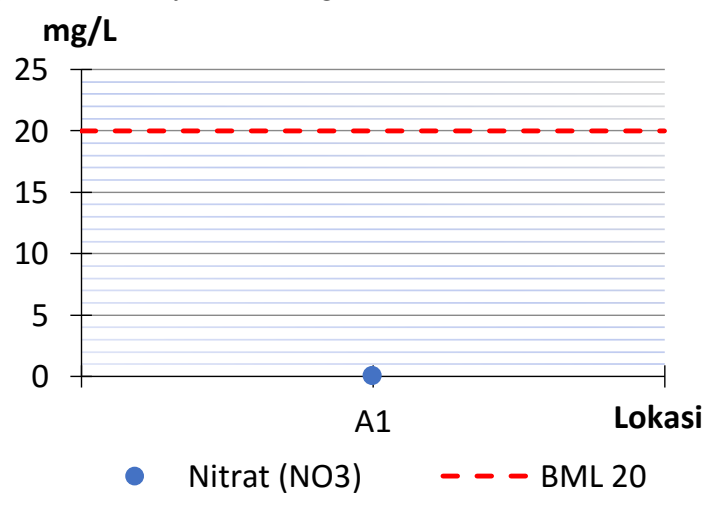

Gambar 16. Nitrat $\left(\mathrm{NO}_{3}\right)$

\section{m. Nitrit $\left(\mathrm{NO}_{2}\right)$}

Nitrit merupakan bentuk peralihan (intermediate) antara amonia dan nitrat (nitrifikasi) dan antara nitrat dengan gas nitrogen (denitrifikasi) yang berlangsung pada kondisi anaerob. Keberadaan nitrit menggambarkan berlangsungnya proses biologis perombakan bahan organik yang memiliki kadar oksigen terlarut sangat rendah. Kandungan nitrit $\left(\mathrm{NO}_{2}\right)$ pada lokasi pemantauan adalah $0,002 \mathrm{mg} / \mathrm{L}$, sehingga hasil tersebut tidak melebihi kadar maksimum baku mutu yang diperbolehkan yakni $0,06 \mathrm{mg} / \mathrm{L}$ berdasarkan pada PP No. 82 Tahun 2001 kategori air kelas III.

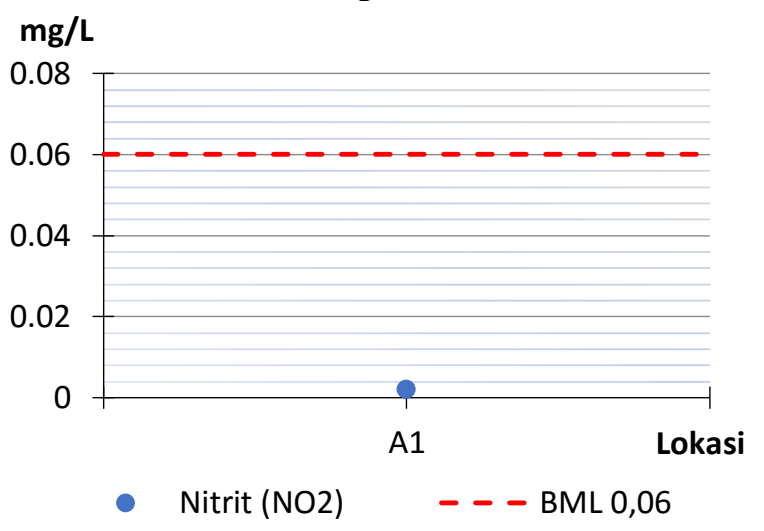

Gambar 17. Nitrit $\left(\mathrm{NO}_{2}\right)$

\section{n. Derajat Keasaman (pH)}

Nilai keasaman memberikan gambaran tentang keseimbangan asam basa dalam air yang sangat erat dengan fungsinya sebagai pelarut dalam reaksi-reaksi kimia. Pengukuran derajat keasaman $(\mathrm{pH})$ di lapangan dilakukan dengan menggunakan pH-meter. Nilai kemasaman dipengaruhi oleh beberapa faktor antara lain oleh proses fotosintesis dalam perairan. Hasil pengukuran konsentrasi $\mathrm{pH}$ di titik lokasi pemantauan adalah 7,73. Nilai ini berada pada kadar dengan konsentrasi $\mathrm{pH}$ netral. Pemantauan $\mathrm{pH}$ dilakukan untuk mengetahui tingkat pencemaran karena dalam kondisi asam diperkirakan ada beberapa jenis asam yang terkandung seperti asam sulfida dan bersifat basa akibat adanya amoniak. Dari sisi lain kondisi $\mathrm{pH}$ yang jauh dari netral baik asam maupun basa akan mengganggu kondisi biota perairan di sungai.

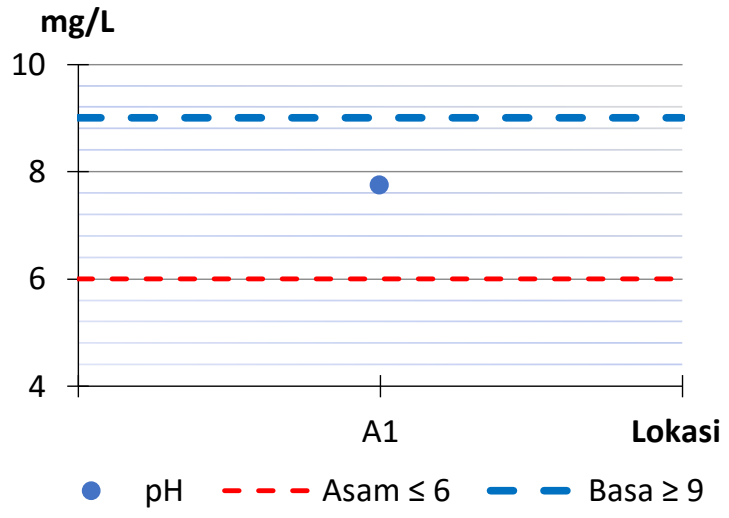

Gambar 18. Derajat Keasaman (pH)

\section{o. $\quad$ Seng $(\mathrm{Zn})$}

Konsentrasi seng dalam air alami umumnya rendah, tetapi dalam beberapa perairan ditemukan dalam konsentrasi yang relatif tinggi. Seng dalam konsentrasi yang tinggi selalu ditemukan dalam air yang tercemar 
atau air yang mengalir melalui sistem batuan dasar (bedrock) yang mengandung deposit seng. Rendahnya kandungan logam $\mathrm{Zn}$ di perairan kemungkinan disebabkan oleh sifat logam $\mathrm{Zn}$ dalam lingkungan perairan dan sangat dipengaruhi oleh bentuk senyawanya. Kelarutan logam $\mathrm{Zn}$ dalam air relatif rendah, logam $\mathrm{Zn}$ dengan gugusan klorida dan sulfat mudah terlarut ke dalam sedimen, sehingga logam $\mathrm{Zn}$ di perairan banyak mengendap di dasar. Logam seng cenderung membentuk ion jika berada dalam air. Ion seng mudah terserap dalam sedimen dan tanah serta kelarutan logam berat seng dalam air relatif rendah pada air, logam berat cenderung mengikuti aliran air dan pengaruh pengenceran ketika ada air yang masuk, seperti air hujan, turut mengakibatkan menurunnya konsentrasi logam berat pada air. Kadar seng di titik lokasi adalah 0,01 $\mathrm{mg} / \mathrm{l}$ dengan baku mutu lingkungan yang diperbolehkan adalah $0,05 \mathrm{mg} / \mathrm{l}$. Apabila logam berat seng di dalam air melebihi baku mutu dapat menyebabkan gangguan kesehatan terhadap manusia yang mengkonsumsinya, walaupun seng merupakan logam yang dibutuhkan oleh tubuh namun berbahaya jika melebihi ambang batas dan dapat menimbulkan rasa kesat pada air.

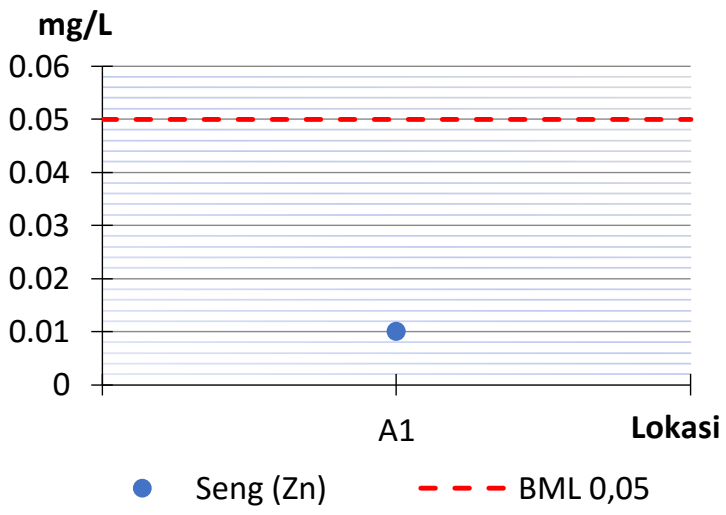

Gambar 19. Seng (Zn)

\section{p. Timbal $(\mathbf{P b})$}

Timbal/ timah hitam $(\mathrm{Pb})$ pada perairan ditemukan dalam bentuk terlarut dan tersuspensi. Kelarutan cukup rendah sehingga kadar di dalam air sedikit. Sumber alami utama adalah Galena (PbS), Gelesite $\left(\mathrm{PbSO}_{4}\right)$ dan Cerrusite $\left(\mathrm{PbCO}_{3}\right)$. Bahan yang mengandung memberikan kontribusi yang berarti bagi keberadaan di dalam air. Di perairan tawar, membentuk senyawa kompleks yang memiliki sifat kelarutan rendah dengan beberapa anion, misalnya Hidroksida, Carbonat, dan Sulfat. Perairan tawar alami biasanya memiliki kadar $<0,03 \mathrm{mg} / \mathrm{L}$. Kadar diperairan yang diperuntukan bagi keperluan pertanian pada tanah yang bersifat netral dan alkalis adalah $10 \mathrm{mg} / \mathrm{L}$, sedangkan pada tanah yang bersifat asam adalah $5 \mathrm{mg} / \mathrm{L}$. Kandungan Timbal $(\mathrm{Pb})$ yang terdapat pada lokasi pemantauan adalah $0,00 \mathrm{mg} / \mathrm{l}$ berada di bawah baku mutu yang diperbolehkan yakni sebesar $0,03 \mathrm{mg} / \mathrm{L}$.

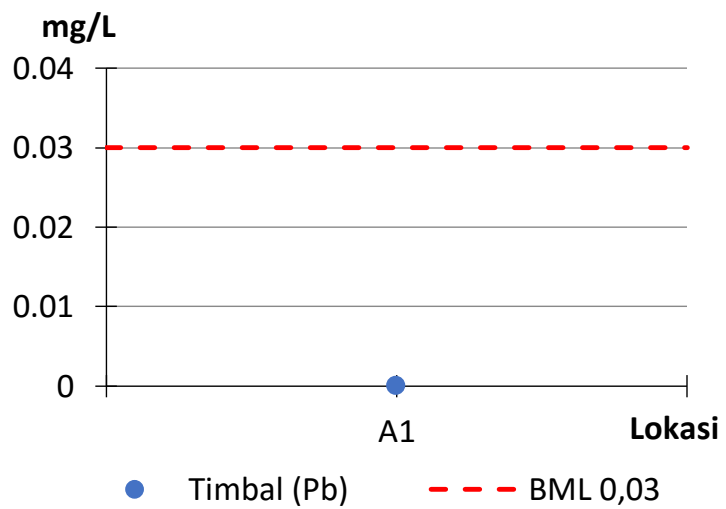

Gambar 20. Timbal $(\mathrm{Pb})$

\section{q. Sulfat $\left(\mathrm{SO}_{4}\right)$}

Sulfat merupakan salah satu elemen yang esensial bagi mahluk hidup, karena merupakan elemen penting dalam protoplasma. Ion sulfat yang bersifat larut dan merupakan bentuk oksidasi utama sulfur adalah salah satu anion utama diperairan, menempati urutan kedua setelah bikarbonat. Apabila di perairan tidak terdapat oksigen dan nitrat maka sulfat berperan sebagai sumber oksigen dalam proses oksidasi yang dilakukan oleh bakteri anaerob. Kadar sulfat pada perairan alami berkisar antara $2-80 \mathrm{mg} / \mathrm{L}$. Kadar sulfat air minum sebaiknya tidak melebihi $400 \mathrm{mg} / \mathrm{L}$. Kadar sulfat yang melebihi $500 \mathrm{mg} / \mathrm{L}$ dapat mengakibatkan terjadinya gangguan pada sistem pencernaan. Hasil analisis kandungan sulfat $\left(\mathrm{SO}_{4}\right)$ di lokasi pemantauan adalah sebesar $<0,4629 \mathrm{mg} / \mathrm{L}$.

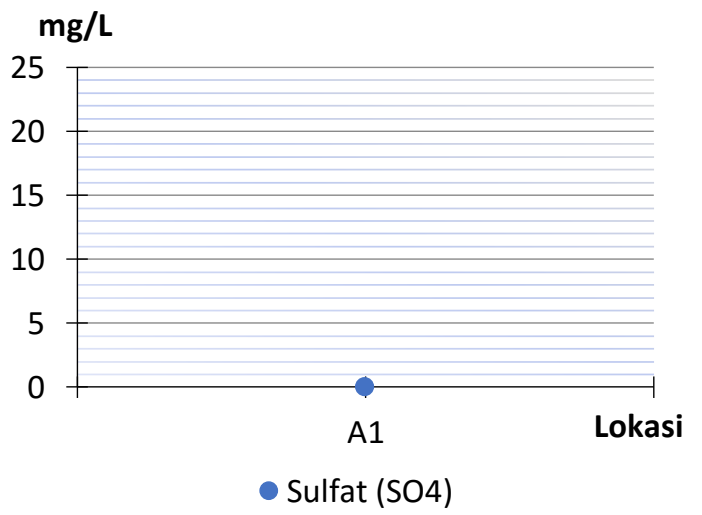

Gambar 21. Sulfat $\left(\mathrm{SO}_{4}\right)$

\section{r. Tembaga $(\mathrm{Cu})$}

Tembaga $(\mathrm{Cu})$ merupakan salah satu logam berat yang dapat ditemukan pada lingkungan perairan maupun dalam sedimen. Keberadaan unsur tembaga di alam dapat ditemukan dalam bentuk logam bebas, akan tetapi lebih banyak ditemukan dalam bentuk persenyawaan. $\mathrm{Cu}$ termasuk ke dalam kelompok logam essensial, dimana dalam kadar yang rendah dibutuhkan oleh 
organisme sebagai koenzim dalam proses metabolisme tubuh, sifat racunnya baru muncul dalam kadar yang tinggi. Logam berat secara alami memiliki konsentrasi yang rendah pada perairan. Tinggi rendahnya konsentrasi logam berat disebabkan oleh jumlah maksimum limbah logam berat ke perairan. Logam berat yang masuk perairan akan mengalami pengendapan, pengenceran dan dispersi, kemudian diserap oleh organisme yang hidup diperairan. Dari hasil laboratorium, diperoleh kandungan tembaga pada perairan di titik lokasi adalah 0,009 mg/L, sedangkan kadar tembaga maksimum yang diperbolehkan berdasarkan PP RI No. 82 Tahun 2001 kategori air kelas III adalah 0,02 mg/L. Tinggi rendahnya kandungan tembaga bias diakibatkan adanya proses akumulasi logam pada sedimen, yang dapat disebabkan karena logam berat mempunyai sifat yang mudah mengikat bahan organik dan mengendap di dasar perairan dan bersatu dengan sedimen, selain itu dimungkinkan logam berat yang terdapat dalam sedimen sudah terakumulasi dalam waktu yang lama sebelum pengambilan sampel, sehingga pada saat dilakukan analisis kandungan tembaga dalam sedimen menunjukkan kadar yang tinggi.

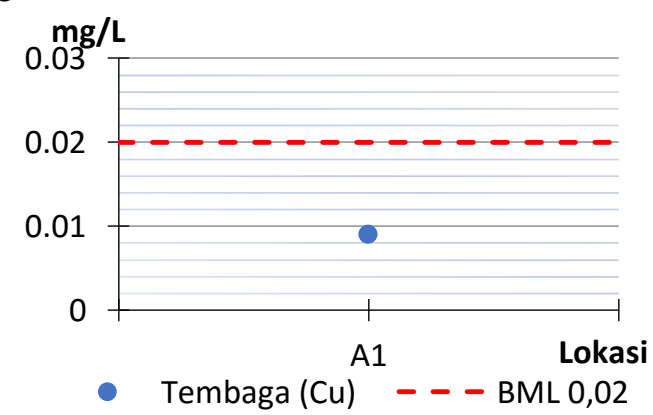

Gambar 22. Tembaga $(\mathrm{Cu})$

\section{Kesimpulan}

Dari hasil pemeriksaan kualitas air permukaan, dapat dilihat bahwa hampir semua parameter pencemaran air di lokasi masih berada dibawah baku mutu lingkungan kategori Air Kelas III berdasarkan Peraturan Pemerintah No. 82 Tahun 2001 tentang Pengelolaan Kualitas Air dan Pengendalian Pencemaran Air. Hanya satu parameter di titik lokasi yang melebihi baku mutu, yaitu BOD. Sehingga dapat dikatakan bahwa kualitas air irigasi di Daerah Irigasi Lubuk Antuk masih memenuhi baku mutu yang telah ditetapkan

\section{Ucapan Terima Kasih}

Terima kasih disampaikan kepada Universitas Panca Bhakti yang telah mendanai keberlangsungan penelitian ini.

\section{Daftar Pustaka}

Akbar, J. (2010). Unsur Nitrogen dan Perannya Terhadap Pertumbuhan Tanaman [internet]. [diacu 2019 Nopember 22]. Tersedia dari: http://www.wordpress.com/2010/03/23/unsurnitrogen-dan-perannya-terhadap-pertumbuhantanaman.

Akmal, Masimin, dan Mellianda, E. (2014), Efisiensi Irigasi Pada Petak Tersier di Daerah Irigasi Lawe Bulan Kabupaten Aceh Tenggara. Jurnal Teknik Sipil Pascasarjana Universitas Syiah Kuala, 3(3), 20-37.

Ariffin. (2002). Cekaman Air dan Kehidupan Tanaman. Unit Penerbitan Fakultas Pertanian Universitas Brawijaya.

Effendi, H. (2003). Telaah Kualitas Air bagi Pengelolaan Sumber Daya dan Lingkungan Perairan. Cetakan kelima. Yogyakarta: Kanisius

Kementerian Lingkungan Hidup. (2003). Keputusan Menteri Negara Lingkungan Hidup Nomor 115 tahun 2003 tentang Pedoman Penentuan Status Mutu air, Jakarta

Kurnia, U. (2004). Prospek Pengairan Pertanian Tanaman Semusim Lahan Kering. Jurnal Litbang Pertanian, 4(23), 130-138.

Kodoatie, J. dan Roestam, S. (2008). Pengelolaan Sumber Daya Air Terpadu. Edisi Revisi. Yogyakarta: Andi

Linsley, R.K., dan Joseph B.F. (1995). Teknik Sumberdaya Air. Jakarta: Erlangga. (diterjemahkan oleh Djoko Sasongko).

Maryono, A. (2005). Eko-Hidraulik Pembangunan Sungai. Edisi Kedua. Magister Sistem Teknik Program Pascasarjana Universitas Gadjah Mada. Yogyakarta.

Pemerintah Republik Indonesia. (2001). Peraturan Pemerintah Nomor 82 tahun 2001 Tentang Pengelolaan Kualitas Air dan Pengendalian Pencemaran Air. Jakarta.

Pemerintah Republik Indonesia. (2006). Peraturan Pemerintah Republik Indonesia Nomor 20 Tahun 2006 Tentang Irigasi. Jakarta.

Rao, C. S., (1992). Environmental Pollution Control Engineering. New Delhi: Wiley Eastern Limited.

Saeni, M.S. (1996). Kimia Lingkungan. Depdikbud dan PAU Ilmu Hayat IPB. Bogor

Sosrodarsono, S. dan Takeda, K. (2003). Hidrologi untuk Pengairan. Jakarta: Pradna Paramita. 